\title{
Die effek van finansiële trauma na aftrede op eiewaarde
}

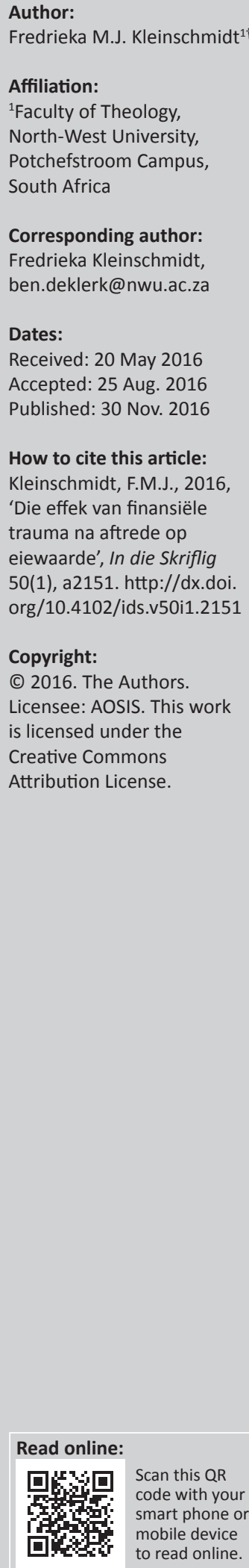

\begin{abstract}
The effect of financial trauma after retirement on selfworth. The South African community, as communities worldwide, is characterised by longevity. This results in a steadily increasing number of people still retiring in accordance with the current retirement policy at the ages 60 to 65 years, despite the higher life expectancy. The rising cost of living, unforeseen events and circumstances as well as the fact that retirees 'outlive' their retirement funds, result in an increased number of retirees experiencing financial need. In a recent study by the author the effect thereof, especially on self-worth, was investigated. It became evident that pastors are often not sufficiently informed or equipped to recognise and deal with the negative emotions experienced by elderly people who had not lived in chronic poverty, but had become impoverished after retirement. The urgent need for a better understanding of the causes and extent of financial trauma after retirement and the effect thereof on selfworth compelled the author to conduct an investigation into the matter with the aim of providing a holistic approach to pastoral guidance.
\end{abstract}

\section{Inleiding}

Hierdie artikel poog om 'n beter verstaan teweeg te bring met betrekking tot die oorsake, omvang en uitwerking van finansiële trauma na aftrede en hoe hierdie kennis kan bydra tot 'n holistiese benadering tot eiewaarde in die pastorale versorging van afgetredenes in finansiële nood. Die Verklarende Afrikaanse Woordeboek definieer eiewaarde soos volg: 'hoë skatting van jou eie betekenis' (Labuschagne \& Eksteen 2010:239). In die Vaktaalkomitee vir Maatskaplike werk (1995:58) word eiewaarde as "n persoon se persepsie en evaluering van homself en sy rolvervulling' omskryf. Volgens Collins (2005:365) verwys eiewaarde 'na die manier waarop 'n mens sy of haar waarde, bekwaamheid en belangrikheid beoordeel. Terwyl selfbeeld en selfkonsep 'n selfbeskrywing behels, behels eiewaarde self-evaluering.'

In die sielkunde word die term self-esteem gebruik om 'n persoon se algemene gevoel van eiewaarde of persoonlike waarde te beskryf. Abraham Maslow voer aan dat mense die agting van ander mense sowel as innerlike selfrespek nodig het om as mens te groei en selfaktualisering te bereik (Cherry n.d.).

Die persepsie van eiewaarde hang dikwels saam met sosio-ekonomiese status (SES). By volwassenes, anders as by kinders en adolessente, word SES 'verdien': 'For self-esteem, it is not enough to simply enjoy the perks of high status; one must have had something to do with it' (Twenge \& Campbell 2002:70). Opvoeding, beroep en inkomste het dus 'n direkte invloed op eiewaarde. By afgetredenes verdwyn die komponent van inkomste ter bepaling van SES en gevolglik ook van eiewaarde, maar die vlak van opvoeding en die beroep wat beoefen is, bly steeds belangrike faktore (Twenge \& Campbell 2002:61). Ebaugh, soos aangehaal deur Reitzes, Mutran en Fernandez (1996:651), verwys na hierdie verskynsel as die 'hang-over identity'. Hulle waarneming is dat afgetredenes voortgaan om op hulle eks-identiteit te steun as ' $n$ basis of raamwerk vir die bepaling van hulle eiewaarde.

Gesien vanuit ' $n$ teologiese perspektief is die mens se waarde geleë in die konsep geskape te wees na die beeld van God (imago Dei) soos ons dit vind in Genesis 1:26, 27 en 9:6. Volgens Calvyn word hierdie beeld van God na die sondeval deur Christus herstel 'in die ware en volkome staat van regtheid voor God' (Duvenage 2009:51). Om na die beeld van God geskape te wees, beteken dat baie van ons emosies en eienskappe iets van God se eienskappe weerspieël. Danksy hierdie wete kan ons oortuig wees van ons eiewaarde. Ouer persone beskou hulleself dikwels as irrelevant, magteloos en minderwaardig (Anderson 2009:104-105) ten spyte daarvan dat die mens selfs ná die sondeval as weinig minder as 'n hemelse wese beskryf word (Ps 8 -1983-vertaling). Finansiële

Note: $\uparrow, 1946-2016$. 
posisie en selfstandigheid speel dus geen rol in die waardebepaling van 'n persoon nie, hoewel Anderson (2009:114) daarop wys dat: 'society tends to value those who are able to produce and who are independent'.

Die navorsingsvraag van hierdie artikel is: Hoe kan 'n beter verstaan teweeg gebring word met betrekking tot die oorsake, omvang en uitwerking van finansiële trauma na aftrede en hoe kan hierdie kennis bydra tot ' $n$ holistiese benadering in die pastorale versorging van afgetredenes in finansiële nood? Dit word aan die hand van die vier momente van Osmer se model (2008:4-12) gedoen, naamlik die beskrywendempiriese taak, die interpreterende taak, die normatiewe taak en die pragmatiese taak. Oorweging word geskenk aan die komplekse aard van aftrede ingevolge die huidige beleid, die oorsake en die effek van finansiële nood na aftrede, die rol wat godsdiens en die geloofsgemeenskap in die herstel van eiewaarde kan speel, en die praktiese bydrae wat pastors en beraders kan lewer.

\section{Beskrywend empiriese taak Die kompleksiteit van aftrede}

Aftrede is geen eenvoudige saak nie. Benewens 'n verskeidenheid redes vir aftrede, bestaan daar ook verskillende vorme van aftree-inkomste - elk met 'n eie stel reëls en voorwaardes. Geslag, sosiale status (social class), of aftrede vrywillig of gedwonge plaasgevind het, op watter ouderdom dit plaasgevind het, die emosionele ingesteldheid teenoor aftrede, verhoudings, die finansiële posisie sowel as die algemene gesondheidstoestand van die afgetredene is faktore wat tot die kompleksiteit van hierdie lewensfase bydra: 'Given these sources of variety, it is obviously ill advised to speak of retirement as a single type of transition that has only a narrow range of effects' (Atchley 1982:121).

Vanweë die ouderdom waarop dit plaasvind, word aftrede as die kritieke laaste lewensfase ervaar. Doelwitte wat nog nie met die aanbreek van hierdie fase bereik is nie, sal die afgetredene met 'n gevoel van futiliteit laat worstel met die vraag na die sin van die lewe (Brunsdon \& Lotter 2008:286). Volgens Coetzer en Kotze $(2007: 4,7)$ is die psigologie in staat om die biologie te beïnvloed. Die emosies wat 'n skadelike uitwerking op die liggaam het, stem grootliks ooreen met dié wat afgetredenes in finansiëlenood ervaar, naamlikwoede, onvergewensgesindheid, depressie, bekommernis, frustrasie, skuldgevoelens, angs en droefheid. Volgehoue negatiewe gedagtes en emosies kan 'n persoon se fisiese gesondheid negatief beïnvloed. Respondente wat 'n aantal vrae oor hulle belewing van finansiële nood na aftrede beantwoord het, het erken dat hulle woede, haat, bitterheid, vernedering, minderwaardigheid, eensaamheid, verwerping en skuldgevoelens ervaar het (Kleinschmidt 2016:53-55). Sommige worstel na verloop van etlike jare steeds met hierdie emosies.

Oor die algemeen word mense se ingesteldheid teenoor aftrede bepaal deur hulle finansiële posisie. Hoe hoër die verwagte inkomste na aftrede, hoe gunstiger die ingesteldheid.
Werk vir diegene wat dit moeilik vind om na aftrede die begroting te laat klop, is uiters skaars (Atchley 1982:122, 123). In sy navorsing het Ramashala (2001) bevind dat:

material security is one of the greatest preoccupations of old age. Many experience the same lack of physical necessities, assets and income felt by other poor people, but without the resources that younger, fitter and more active adults can use to compensate. (p. 6)

Finansiële nood word as een van die grootste redes vir die hoë selfdoodsyfer onder ouer mense beskou (Shreve-Neiger 2002:2). Ander faktore soos depressie, spanning, swak gesondheid, sosiale isolasie en alkoholisme is dikwels uitvloeisels van finansiële probleme wat negatief op die afgetredene se persepsie van sy of haar eiewaarde inwerk.

Weens die politieke situasie in Suid-Afrika is die wenslikheid van aftrede op 'n hoër ouderdom 'n kwessie wat wyd gedebatteer word. Finansiële adviseurs waarsku feitlik daagliks dat individue hulle aftreefondse gaan 'oorleef'. 'Add to this the fact that relationships between employers and employees are changing, that secure tenure of work is fast becoming obsolete and it becomes clear that the pension industry will have to reinvent itself' (Müller 2013:6). Nogtans is politici huiwerig om hulle ten gunste van 'n hoër aftree-ouderdom uit te spreek weens die hoë werkloosheidsyfer. Faurie (2014) haal Craig Aitchison van Old Mutual aan wat daarop wys dat so 'n stap enersyds ongewild sal wees omdat dit die moontlikhede van indiensneming vir die jonger geslag kan benadeel. Andersyds beteken 'n hoër aftree-ouderdom dat werknemers meer kan bydra tot die nasionale besparingskoers wat groter groeigeleenthede vir ons ekonomie in die hand sal werk.

\section{Finansiële trauma na aftrede}

In Suid-Afrika ondervind al hoe meer afgetredenes en ouer mense finansiële probleme weens 'n verskeidenheid redes. Hierdie situasie neem sulke ernstige afmetings aan dat die regering deur wetgewing wil ingryp om mense te verhoed om toegang tot hulle aftreefondse te verkry wanneer hulle uit hul poste bedank (Du Preez \& Arde 2011). Die hoofrede is dat hierdie geld dikwels onoordeelkundig bestee word, met die gevolg dat al hoe meer mense van die staat se ouderdomspensioen afhanklik raak. Sedert September 2015 ontvang 3.1 miljoen mans en vroue ouer as 60 jaar 'n staatspensioen. Die totale aantal persone wat maatskaplike toelaes ontvang, beloop 16.9 miljoen (Ferreira 2016). Dit maak Suid-Afrika die vrygewigste welsynstaat in die wêreld - 'n situasie waaroor ekonome dit eens is dat dit nie volhoubaar is nie (Smit 2011).

Die implikasies van die huidige beleid waarvolgens werknemers tussen die ouderdomme van 60 en 65 jaar aftree, dra direk daartoe by dat die persentasie ekonomies aktiewe mense drasties afneem. Volgens Bekker (2009):

[d]ie geboorteaanwas in ontwikkelende lande is onder die groeikoers. Dit plaas 'n groot druk op ekonomiese groei en fondse vir pensioene, mediese sorg en welsynsdienste. Dit is al bestempel as 'n dreigende ramp. (bl. 14) 
In 1950 het 16 werkendes een pensioentrekker ondersteun teenoor die huidige 3.3 werkers per pensioenaris. Volgens Eurostat se projeksie wat in 2008 vrygestel is, sal daar teen 2060 in die Europese Unie slegs twee werkendes (ouderdom 15-64) wees vir elke persoon ouer as 65 (Goldenworkers 2012).

Navorsing wat by Old Mutual Corporate gedoen is waarvan die resultate in Die Burger (Watson, Van Zyl \& Saayman 2013:18) gepubliseer is, dui daarop dat $85.0 \%$ van mense bo 55 bang is dat hulle nie genoeg geld sal hê vir aftrede nie. Hulle glo dat hulle na die aftree-ouderdom van 61 moontlik nog 17 jaar sal leef. Syfers wat deur Alexander Forbes vrygestel is, toon dat, teen 'n inflasiekoers van $6.0 \%$, die waarde van afgetredenes se geld na 12 jaar gehalveer word (Watson et al. 2013:15). In Februarie 2016 het die inflasiekoers op $6.9 \%$ gestaan, terwyl voedselinflasie in Maart 9.5\% beloop het (Taborda 2016). Mediese inflasie het in Desember 2015 vir die vierde agtereenvolgende maand op $11.5 \%$ gestaan bykans $5.0 \%$ hoër as die algehele inflasiekoers (Nkabinde 2016). Dit beteken dat afgetredenes se geld teen die huidige koers selfs in minder as 12 jaar gehalveer word, terwyl noodsaaklike uitgawes steeds styg.

\section{Die interpreterende taak Oorsake van finansiële nood na aftrede}

Tydens 'n opname wat in 2014 deur Sanlam gedoen is, is bevind dat slegs 13\% van respondente hulle lewenstandaard na aftrede kon handhaaf (Pickworth 2014). Volgens Cameron en Heystek, soos aangehaal deur De Beer (2011:808), het werknemers en werkgewers se bydrae tot aftreefondse dieselfde gebly ongeag die hoër lewensverwagting. Dit bring mee dat afgetredenes hulle al meer in 'n situasie bevind waar hulle hul aftreefondse oorleef (Brunsdon \& Lotter 2008:296). Navorsingsresultate wat in 2013 in die Verenigde Nasiespublikasie World Population Aging (sien Kleinschmidt 2016:22) gepubliseer is, dui daarop dat hoewel ouer mense in die meeste OECD-lande (Organisation of Economic Co-operation and Development) oor die algemeen voldoende steun ontvang van maatskaplike beskermingsdienste (social protection services), die armoedesyfer onder afgetredenes steeds hoër is as die bevolkingsgemiddeld.

Uit inligting verkry van respondente (Kleinschmidt 2016:40, 41, 44-47), blyk dit dat onvoorsiene uitgawes soos groot mediese koste, stygende heffings en eiendomsbelasting, verkeerde beleggingsbesluite, bedrog, finansiële hulp aan volwasse kinders, die versorging van kleinkinders en borgstaan rampspoedige gevolge kan hê. Behuising wat aanvanklik bekostigbaar was, raak weens die gebruiklike eskalasie spoedig onbekostigbaar. Hierdie faktore verplig die afgetredene dikwels om 'n alternatiewe bron van inkomste te vind of om drastiese maatreëls te tref ter wille van oorlewing. Dit gebeur byvoorbeeld dat afgetredenes, wat gebruik maak van maaltye wat teen minimale koste deur dienssentrums voorsien word, versoek om slegs drie maaltye per week te ontvang. Hierdie maaltye word dan gedeel om die hele week te hou.
Die finansiële probleme van afgetredenes word vererger deur die feit dat hulle 'n hoër inflasiekoers as die res van die bevolking ondervind, naamlik $15 \%$ teenoor die inflasiekoers van 6.3\% in Maart 2016 (Statistics SA n.d.). Groot mediese uitgawes is hoofsaaklik hiervoor verantwoordelik. Baie afgetredenes kanselleer hulle mediese fondse en wend hulle tot goedkoper opsies, soos byvoorbeeld 'n hospitaalplan. Dit het tot gevolg dat hulle self vir medikasie en doktorsafsprake moet betaal. Afgetredenes soek werk, maar weens hulle ouderdom is dit ' $n$ bykans futiele oefening.

Gemeentes, veral dié wat 'n groot aantal afgetrede lidmate het, vind dit al moeiliker om hulle verpligtinge teenoor die hulpbehoewendes na te kom. Namate pensioene se waarde verminder, verminder ook die bydraes wat aan die kerk gegee word.

\section{Die effek van finansiële nood na aftrede op eiewaarde}

Maslow se teorie oor die mens se behoefte-hiërargie toon raakpunte met Erik Erikson se ontwikkelingsfases in dié opsig dat elke behoefte of fase eers bevredig of bemeester moet word voordat suksesvol na die volgende behoefte of fase oorgegaan kan word (McLeod 2008). Volgens Maslow moet daar eers aan die basiese behoeftes voldoen word voordat die behoefte aan selfverwesenliking (actualisation) sal ontstaan. Vordering word dikwels ontwrig wanneer daar nie aan die basiese behoeftes voldoen word nie. 'Life experiences including divorce and loss of job may cause an individual to fluctuate between levels of the hierarchy' (McLeod 2008). Ten spyte van geregverdigde kritiek teen Maslow se teorie, het navorsers bevind dat afgetredenes wat finansiële nood ervaar, noodgedwonge terugkeer na die bevrediging van die basiese behoeftes wat bestaan uit kos, veilige huisvesting en klere (vgl. May 2003; Ramashala 2001; ShreveNeiger 2002). Respondente het bevestig dat die stryd om oorlewing noodwendig prioriteite wysig. 'n Lewenstyl wat voorheen as vanselfsprekend beskou is, moes drasties aangepas word om aan die basiese behoeftes te voldoen (Kleinschmidt 2016:50-51).

Daar is aanduidings dat die besef van finansiële nood weens onvoorsiene omstandighede volgens die tipiese fases van rou verloop, soos beskryf deur dr Elizabeth Kubler-Ross in haar boek On Death and Dying, gepubliseer in 1969 (sien Patricelli n.d.). Hierdie stappe bestaan uit ontkenning, woede, onderhandeling, depressie en aanvaarding. Uit die reaksie van respondente kan die gevolgtrekking gemaak word dat finansiële probleme na aftrede, indien nie aanvanklik nie, wel met verloop van tyd 'n negatiewe uitwerking op die individu se gevoel van eiewaarde het en dat dit interaksie op verskeie vlakke nadelig affekteer (Kleinschmidt 2016:53-54).

Soos reeds genoem, word finansiële nood na aftrede as een van die sterkste oorsake van die hoë selfdoodsyfer onder ouer mense beskou. Wheaton se navorsing (1994:102) plaas finansiële probleme tweede op die lys van die oorsake van ernstige depressie. Die onbekostigbaarheid van gerieflike, 
veilige behuising (Collins 2005:245, 246), die hoë koste van mediese dienste (Moneyweb 2014), onttrekking aan sosiale geleenthede weens duur kaartjies, hoë brandstofpryse en die onvermoë om goed aan te trek, lei tot isolasie, vereensaming, depressie (Coetzer 1993:119, 121; Ramezani 2011:73) en selfs alkoholisme of dwelmverslawing (Gossop 2008; HealthinAging 2012). Sosiale isolasie is volgens Sarason, Pierce en Sarason (1994:152) deur verskeie studies aangewys as 'n 'major risk factor in mortality from widely varying causes'. Isolasie lei dikwels tot gebrekkige verhoudings en vereensaming wat die risiko van dood verder verhoog.

In 'n opname wat in Mei 2012 deur die American Association for Retired Persons (AARP) gedoen is, is bevind dat die meerderheid vroeg-bejaarde werkendes of werksoekers hulle hoofsaaklik om finansiële redes in hierdie posisie bevind het (Gerstein 2013:16). Omdat poste vir ouer mense skaars is, ervaar'n groot persentasie van hulle uiterste frustrasie omdat hulle 'n produktiewe rol in die gemeenskap ontsê word. Dit bevorder die aftakelingsproses wat tot vroeë afhanklikheid lei. Volgens Müller en Stevens (2001:15-20) veroorsaak 'die verlies aan sinvolle werk, sosiale aansien en inkomste wat met aftrede gepaard gaan, dikwels so 'n groot trauma dat ' $n$ mens letterlik daaraan kan doodgaan'.

Finansiële probleme word ook as een van die belangrike oorsake van verslawing by afgetredenes beskou (Gossop 2008). Daar is verder bevind dat finansiële probleme by ouer mense dikwels lei tot vereensaming en isolasie (Twenge \& Campbell 2002:61; Coetzer 1993:119), depressie (BBC News 1999; Ramezani 2011:18) en gesondheidsprobleme weens die belewing van emosies wat mense fisies siek maak soos bekommernis, vrees en frustrasie (Coetzer \& Kotze 2007:4).

Min navorsing is gedoen oor die verband tussen stresvolle gebeure soos finansiële nood na aftrede en die individu se persepsie van eiewaarde. Bevindinge wissel egter: Een studie het bevind dat stresvolle gebeure wel 'n uitwerking op die gevoel van eiewaarde het (Joiner et al. 1999:274), terwyl 'n ander bevind het dat dit nie 'n beduidende uitwerking daarop het nie (Orth, Robins \& Meier 2009:308). Coleman, Ivani-Chalian en Robinson (1993:172) het bevind dat verlies aan eiewaarde eerder die gevolg kan wees van 'greater rigidity, an inability to find new coping strategies for a changing situation. Continuing self-esteem may indicate that adaptation has occurred'.

Die manlike respondente het aangedui dat hulle hul verlies aan SES beleef as 'n aantasting van hulle menswaardigheid. In hierdie verband huldig Krause (1996:665-666) die standpunt dat 'sex role expectations and experiences create fundamental differences in the way that older men and women relate to financial matters'. Krause (1996:669) voer verder aan dat die media as die 'generalized others', 'n uiters belangrike rol speel by die wyse waarop persone in finansiële nood hulleself evalueer. Mense wat hulleself vir hul situasie blameer, internaliseer makliker die negatiewe terugvoer van ander. Krause (1996:669) het verder bevind dat die eiewaarde van ouer mans wat staatshulp ontvang weens hulle tradisionele rol as voorsieners, in 'n groter mate negatief daardeur beïnloed word. Ouer vroue is meer geneig om hulle eiewaarde te meet ooreenkomstig hulle vermoë om goeie verhoudings te handhaaf.

Staatstoelae en ander hulpprogramme vir bejaardes, byvoorbeeld pensioenariskaarte wat afslag op aankope bied, spesiale tariewe by teaters en vermaaklikheidsgebeure, en pensioenarisdae by sekere supermarkte bied finansiële verligting vir baie afgetredenes in nood. Die negatiwiteit waarmee hierdie hulpprogramme deur die algemene publiek bejeën word, lei egter daartoe dat afgetredenes wat daarvan gebruik maak dikwels gestigmatiseer word. Hulle word as mislukkings, lui, onbetroubaar en onbevoeg beskou (vgl. Coetzer 1993; Krause 1996; Rank 1994).

Dit is egter nie alle ouer persone wat 'n staatstoelaag ontvang wat noodwendig 'n afname in eiewaarde ervaar nie. Krause (1996) bevind dat:

$[A]$ s investigators began to learn more about this process, it quickly became evident that there is no one-to-one correspondence between exposure to stigma and subsequent decline in feelings of self-worth. (pp. 665, 667)

Krause huldig die standpunt dat geslag 'n rol speel by die wyse waarop ouer mans en vroue finansiële probleme ondervind - met die eiewaarde van ouer mans wat meer geredelik negatief daardeur beïnvloed word. Die beskouing dat mans verantwoordelik is vir langtermyn finansiële beplanning bring mee dat vroue hulleself nie blameer indien sodanige beplanning gebrekkig blyk te wees nie.

\section{Die normatiewe taak Die rol van godsdiens in finansiële trauma:}

Daar word wyd aanvaar dat godsdiens of spiritualiteit toeneem in belangrikheid namate mense ouer word. In die Gallup-opname wat in 2010 in Amerika gedoen is, het 69\% van respondente ouer as 65 verklaar dat godsdiens vir hulle baie belangrik is teenoor $45 \%$ van respondente jonger as 30 (Moreno-Weinert 2011:17). Volgens die mees onlangse sensusopname (2001) waarvan die syfers oor godsdienstige affiliasie bekend is, behoort slegs $15 \%$ van Suid-Afrikaners aan geen godsdiens nie (Media Club South Africa n.d.)

Die mens se geloofsidentiteit, dit wil sê hoe iemand hom- of haarself as godsdienstige persoon sien, vorm 'n belangrike buffer teen die spanning wat met aftrede gepaard gaan. Verskeie studies (vgl. Fry 2000; Krause 2004; Pinquart 2002; Reitzes \& Mutran 2002) het getoon dat 'maintaining more and higher levels of self-meanings were predictive of better physical and mental health'. Jung, soos aangehaal deur Keyes en Reitzes (2007:435), verwys daarna as 'a spiritual outlook on life' - iets wat by baie van sy ouer pasiënte ontbreek het. Frankl (1975:64) het ervaar dat gevangenes wie se soeke na sin in die lewe geblokkeer, verloor of vernietig is, hulle lyding meer intens ervaar. 
In die breë gesien, is godsdiens 'n manier (hoewel nie die enigste manier nie) vir ouer mense om te ontwikkel en aktief betrokke te bly by die lewe. Hierdie mening is reeds in 1916 uitgespreek deur George Albert Coe (sien Krause \& Hayward 2014):

The conviction that one may discern divine operations within one's self; that there is a divinely appointed place and work for everyone; that God will guide one to this work and help one accomplish it - this conviction in a group brings to light abilities otherwise unguessed. (p. 378)

Snodgrass en Sorajjakool (2011) spreek die mening uit dat singewing as ontologiese taak van die lewe veral van deurslaggewende belang is tydens laat volwassenheid. Dit dien as hanteringsmeganisme sowel as motivering vir spirituele ontwikkeling. Wanneer mense - ook ouer mense deur terugslae, teleurstellings en probleme gekonfronteer word, hanteer hulle dit vanuit hulle geloofsoortuigings, persepsie van eiewaarde, optimisme, veerkragtigheid, teologie en filosofie (Snodgrass \& Sorajjakool 2011:87, 88).

Ellison (1991:89) het bevind dat daar 'n korrelasie tussen spiritualiteit en psigologiese welsyn bestaan. Persone met sterkgeloofsoortuigingswataanEllisonsenavorsingsprogram deelgeneem het, het na 'n traumatiese ervaring hoër vlakke van psigologiese welsyn getoon met minder negatiewe gevolge. Sodanige individue herdefinieer potensieel negatiewe ervarings as geleenthede vir geestelike groei (sien Moreno-Weinert 2011):

Religious involvement may offer either or both of two consequences found by investigators to have effects on health and well-being: (1) the reduction of a sense of fatalism or helplessness in the face of unpredictability of the environment and (2) the fostering of a sense of optimism, a perception that things will turn out all right, whether one has any control over them or not. (p. 8)

Hierdie standpunt is deur die respondente onderskryf wat aangedui het dat die erns en die skynbare hopeloosheid van hulle onderskeie situasies tot ' $n$ dieper geloofservaring gelei het (Kleinschmidt 2016:57).

Een van die primêre funksies van godsdiens is dat dit sin aan die lewe van die individu gee. Wanneer geloofsekerheid deur twyfel ondermyn word, lei dit tot pessimisme oor die toekoms. Die vraag of opvoedingspeil 'n invloed op geloofstwyfel het, is deur Krause (2006) ondersoek. Hy postuleer dat opvoeding die vermoë ontwikkel om inligting in te samel en te interpreteer en probleme op verskillende vlakke op te los. Dit verhoog die beheer wat die persoon het oor gebeure en die uitkoms daarvan. Ouer mense wat nie ' $n$ hoë opvoedingspeil bereik het nie, beskik selde oor die vaardighede om met geloofstwyfel te worstel en dit te oorkom. Hierdie onvermoë om twyfel te hanteer, bring verwarring mee wat negatief op eiewaarde inwerk (Krause 2006:290).

Daar bestaan toenemende getuienis dat hoë eiewaarde en die gevoel van in beheer wees tot fisiese en psigiese welsyn bydra. Kim, Nesselroade en McCullough (2009:88) verwys na Hoode se bevinding dat geloofsoortuigings en godsdienstige praktyke drie funksies vervul, naamlik dat dit sin gee aan die lewe, 'n gevoel van persoonlike beheer in die hand werk en eiewaarde bevorder: 'Older people with higher religious commitment report having more hope, sense of purpose, self-esteem and security.' Uit 'n opname wat Krause en Trann (1989) onder ouer mense gedoen het, wil dit voorkom of geloofsoortuigings die negatiewe uitwerking van stresvolle gebeure teenwerk deurdat dit eiewaarde en die persepsie van beheer in stand hou. Dit staaf vorige bevindings dat godsdienstige ouer mense glo dat hulle, met die hulp van God, in staat sal wees om spanningsvolle gebeure en die gevolge daarvan te oorkom.

Die verband tussen die ekonomiese situasie van 'n land en die godsdienstigheid van sy inwoners is deur Braam et al. (2004) ondersoek. Hulle het bevind dat, ten spyte van die beskikbaarheid van mediese dienste in lande met 'n gesonde ekonomie, die hoë koste daarvan dikwels tot depressie by ouer mense lei. Lande wat tradisioneel godsdienstig is en 'n gesonde waardestelsel handhaaf, bied 'n gunstige klimaat vir die aanwending van godsdiens as ' $n$ hanteringsmeganisme vir faktore wat tot depressie lei (Braam et al. 2004:27).

\section{Rol van die geloofsgemeenskap:}

Die begrip gemeenskap verwys na mense wat in samelewingsof groepsverband op so 'n wyse saam verkeer dat die individu in mindere of meerdere mate afhanklik is van en verbonde is aan die groep (Heyns 1986:11). Die aard en struktuur van die verbande en die verhouding waarin dit tot mekaar staan, oefen 'n bepaalde invloed uit op die wyse waarop individue of groepe mekaar behandel. Die sosiaal-etiese lewe van die mens speel binne hierdie samelewingsverbande af waar 'laasgenoemde eersgenoemde fundamenteel bepaal' (Heyns 1986:13). Cooley, soos aangehaal deur Crocker en Major (1989:610), voer aan dat die mens se persepsie van eiewaarde ' $n$ produk is van hoe ander ons beskou en die mate waarin ons daardie beskouing internaliseer. Hierdie verskynsel staan bekend as 'reflected appraisals' of die 'looking-glass self'.

Indien ons ons verbondenheid aan mekaar reg sou verstaan, sou daar 'n besorgdheid en empatie jeens mekaar bestaan het. 'We will rejoice with those who rejoice and weep with those who weep, even if they are not fellow Christians' (Erickson 2001:168; Luk 15:9; Mark 16:10). Heyns (1978:131) postuleer dat ons verbondenheid aan mekaar nie aan die toevallige sameloop van omstandighede toe te skryf is nie, maar dat dit so deur God gewil is in sy bestuur van die geskiedenis en in sy skeppingsopdrag aan die mens. Ons kan ook nie self bepaal wie ons medemens is nie, omdat dit 'elke mens is wat in sy konkrete lewensomstandighede, met sy vreugde en verdriet, sy oorvloed en in sy gebrek, my lewensweg kruis' (Heyns 1978:131).

Maslow se stelling dat die mens die waardering en respek van ander nodig het om tot selfverwesenliking te kom, impliseer dat die persepsie van eiewaarde deur die insette en ingesteldheid 
van ander rolspelers beïnloed kan word (Cherry n.d.). Hierdie standpunt word deur die filosoof Winifred Lamb en die teoloog Heather Thompson onderskryf wat aanvoer dat ons gevoel van eiewaarde grootliks bepaal word deur dit wat ons van ander ontvang (Lamb \& Thompson 2001:61). In hierdie verband speel die kerk, pastors en beraders 'n uiters belangrike rol.

\section{Die pragmatiese taak Die begrip aftrede binne die raamwerk van
roeping en roepingsvervulling}

Die mens se roeping word nie met aftrede beëindig nie. Werk en aftrede vorm saam deel van roepingsvervulling alhoewel dit verskillende fases daarvan verteenwoordig (De Klerk 2005:2). Dit impliseer dus dat aftrede nie die einde van die mens se roeping beteken nie, maar wel dat dit'n nuwe dimensie van roepingsvervulling inlei. Aftrede as 'n laat negentiendeeeuse konsep, behels ' $n$ beroepsritme of beroepsiklus wat 'n totale staking van werk op 'n vasgestelde ouderdom beteken. Hierdie periode eindig eers wanneer die afgetredene te sterwe kom. Daaruit is dit duidelik dat die huidige benadering tot beroepsbeëindiging strydig is met die werkopdrag in Genesis 1:28 en 2:15 omdat dit nie voorsiening maak vir die 'geleidelike afskaling van werk en verantwoordelikhede namate ' $n$ werker se kragte afneem nie'. (De Beer 2011:814). In moderne tye vorm die afgetredene deel van 'n ekonomies aktiewe gemeenskap waarin die ouer nie-werkende se insette nie hoog geag word nie. Sommige afgetredenes en ouer persone se vrees vir sosiale ekskommunikasie is groter as hulle vrees vir die dood. Die ontdekking dat waarde vir God eerder afhang van wie die persoon is as van wat die persoon doen, is van groot religieuse betekenis (De Jong van Arkel 1986:112).

\section{Die kerk as medebepaler van eiewaarde}

Menslike gedrag, wat ook probleemgedrag insluit, kan in groot mate deur die sosiale en fisiese omgewing van die beradene beïnvloed word (Collins 2005:46-47). Dieselfde gemeenskap wat soms die oorsaak van probleme kan wees, kan dikwels ook 'n bron van ondersteuning en genesing wees. Hoewel die mens as enkeling geskape is, kan hy nie sy 'natuurlike vervolmaking' alleen realiseer nie (Heyns 1986:33). Sy aangewesenheid op die gemeenskap vind uiting in sy deelwees van gemeenskappe van wisselende grootte (huwelik, gesin, uitgebreide familie, kerk, volk, staat).

Die gemeenskap, en by uitstek die kerkgemeenskap, speel 'n belangrike rol in die mens se persepsie van eiewaarde. Hoe afgetredenes deur die strukture waarvan hulle deel uitmaak bejeën word, bepaal in 'n groot mate die wyse waarop die self beskou word. In 'n suksesgedrewe gemeenskap steun afgetredenes swaar op die kerk as 'n veilige hawe vir emosionele en spirituele ondersteuning. Vir afgetredenes in finansiële nood is die kerk die enigste 'bekostigbare' plek waar sosiale interaksie kan plaasvind.

Die kerk is 'n belangrike sosiale struktuur wat 'hoop, liefde, vrede, uitdaging en ondersteuning (verskaf) wat mense toerus om die kompleksiteite van die lewe te hanteer'
(Collins 2005:48). In 'n sukses-georiënteerde gemeenskap wat 'n hoë premie op prestasie, voorspoed en rykdom plaas, 'the church should promote the values of love, stewardship, selfdenial and obedience to God' (Vorster 2007:257). Dit impliseer die kerk se diepe betrokkenheid by die gemeenskap met die doel om Christelike norme en beginsels te vestig tot voordeel van almal.

Kerk en samelewing vorm ' $n$ integrale deel van die sosiale interaksie van die mens wat dit dus van kardinale belang maak vir die pastorale begeleiding van ouer mense (Malan \& Dreyer 2009:2). Ook ander navorsing het bevestig dat godsdiens by ouer mense positief met gesondheid en welsyn, satisfaksie, en eiewaarde verbind kan word (vgl. Keyes \& Reitzes 2007; Krause 2006). 'In short, the extant empirical research suggests that spirituality is typically a strength in the lives of older adults' (Hodge, Bonifas \& Chou 2010).

\section{Die rol van pastors en beraders}

Leraars met wie persoonlike sowel as telefoniese gesprekke gevoer is, is in die meeste gevalle nie voldoende ingelig oor die toenemende armoedeprobleem onder hulle ouer lidmate nie en is ook nie genoegsaam bewus van die negatiewe en uitkringende effek daarvan nie. Volgens die takvoorsitter van 'n bekende landwye hulporganisasie word die kwessie dikwels as 'n maatskaplike probleem beskou wat deur die kerk se Diens van Barmhartigheidsaksie met kospakkies, klere en finansiële hulp hanteer word. Waar beskikbare fondse ontoereikend is, word 'n buite-instansie genader. Bewustheid van en sensitiwiteit vir die vernietigende effek van finansiële nood by afgetredenes en pastorale sorg met die oog op die herstel van menswaardigheid, ontbreek grootliks. Malan en Dreyer (2009:1) onderskryf hierdie bevinding wanneer hulle daarop wys dat die pastoraat nie altyd sy rol speel ter versorging van ouer mense nie.

Op die vraag: Watter uitwerking het die besef dat jy in hierdie stadium van jou lewe finansiële nood ervaar op jou gevoel van eiewaarde? het al die respondente terme soos minderwaardig en mislukking gebruik (Kleinschmidt 2016:53-54). Dit is 'n sterk aanduiding dat finansiële nood na aftrede 'n lae selfbeeld en verminderde eiewaarde tot gevolg het. Die herbevestiging van waarde op grond van Skrifuitsprake het ten doel om hoop te vestig: 'Hoop help ons om nie te wanhoop nie en stel energie vry wat ons in staat stel om die krisis die hoof te bied' (Collins 2005:69).

Afgetredenes wat weens hulle finansiële probleme lae eiewaarde ervaar, is geneig tot sosiale onttrekking. Trots en die sensitiwiteit van die situasie weerhou afgetredenes dikwels daarvan om by 'n berader of pastor om hulp aan te klop. Aksiestrategieë wat uiteindelik tot individuele hulpverlening lei, sal dus op innoverende wyse geskep moet word waarby beraders, die leierskap van die betrokke gemeente en gemeenskap betrokke is. Die mikpunt is tweeledig, naamlik om Skrifgefundeerde kriteria vir die bepaling van eiewaarde by alle rolspelers tuis te bring en om hoop te vestig deur haalbare doelwitte te stel. Dit verg 
'n holistiese benadering wat die individu, die gesin en familie, die kerk en die gemeenskap betrek. Die aanbeveling is dan ook dat die kinders van afgetredenes in finansiële nood, waar moontlik, by beradingsgesprekke teenwoordig moet wees of dat die inhoud en resultate van sodanige gesprekke op gereelde basis aan hulle gekommunikeer word met die medewete en goedkeuring van die beradene. Dit is verder noodsaaklik dat opvolggesprekke moet plaasvind en verdere begeleiding verleen word vir solank dit nodig blyk te wees. Omdat ouer lidmate 'n hoë premie plaas op hulle lidmaatskap van en betrokkenheid by die kerk, is dit die aangewese instelling vanwaar aksies geloods kan word om eerstens hierdie norme oor te dra, en tweedens die breë gemeenskap se persepsie van en houding teenoor afgetredenes positief te beïnvloed deur middel van volgehoue bewusmaking.

By die vestiging van Skrifgefundeerde waardes by afgetredenes in finansiële nood, moet die volgende punte oorweging geniet:

- Ons waarde word bepaal deur die feit dat ons deur God geskape is om Hom op aarde te verteenwoordig. Dit verander nie na gelang van ons finansiële welvaart, status, ouderdom of voorkoms nie. Teenoor die wêreld se materialistiese fiksasie op die uiterlike, staan God se onveranderlike maatstaf vir die waarde van die mens.

- Afgetredenes in finansiële nood verrig dikwels noodgedwonge werk wat deur hulleself en die gemeenskap as 'benede' hulle vorige status beskou word. Alle werk is egter 'n roeping van God en dat die afgetredene die fisiese en intellektuele vermoë besit om werk teen vergoeding te verrig om in sy of haar behoeftes te voorsien, is prysenswaardig en moet as 'n godgegewe voorreg en seën beskou word.

- Vir afgetredenes in finansiële nood is die kerk die enigste plek waar hulle sosiaal kan verkeer. Dit beklemtoon die noodsaak van die kerk se betrokkenheid by die gemeenskap om die Christelike norme en beginsels te vestig wat almal sal bevoordeel. Gemeenskapsberading is daarom noodsaaklik om hierdie probleem van lae eiewaarde weens finansiële nood te ondervang.

- Aftrede lei 'n nuwe fase van roepingsvervulling in. Mense verkeer dikwels onder die indruk dat hulle beroep of werk hulle roeping is. Terwyl daar voorbeelde in die Bybel is dat mense vir' $n$ bepaalde taak geroep is, is dit nie hulle primêre roeping nie. Ons is primêr geroep tot 'n verhouding met God deur die verlossingswerk van Jesus Christus aan die kruis. Dus beteken aftrede nie die einde van die mens se roeping nie, maar dit verteenwoordig wel 'n nuwe dimensie van roepingsvervulling. Eweneens bring moeilike omstandighede nie 'n einde aan die individu se roeping nie maar skep 'n nuwe klimaat waarbinne daardie roeping vervul moet word.

- Die mens se grootste behoefte is dié aan eiewaarde. Die wete dat die mens na die beeld van God geskape is en dat hierdie beeld te alle tye universeel is in alle mense, vorm die kern van ons eiewaarde. As Christengelowiges is ons bewus van ons sondigheid, maar ons is ook oortuig van ons verlossing deur die genade van God wat elkeen van ons 'n belangrike deel in die liggaam van Christus maak.

- Volgens die maatstawwe van die wêreld word ons identiteit en waarde deur kulturele paradigmas en rolle bepaal. Ons is wat ons doen en is werd wat ons besit. In Christus besit ons egter ' $n$ identiteit wat los van wêreldse norme en waardes staan. Vanuit 'n eskatologiese perspektief en deur die werking van die Heilige Gees in ons, word ons persepsies aangaande ons menswees en eiewaarde radikaal hervorm (Louw 2012:6, 7).

\section{Slotopmerkings}

Die waarde van die mens in God se ö word nie deur sy status, besittings, ouderdom of enige ander menslike maatstaf bepaal nie. ' $n$ Persoon het waarde op grond van die feit dat hy skepsel van God is, God se verteenwoordiger op aarde is, Christus mens vir hom geword het, die amp waarin God die mens geplaas het en op grond van die werking van die Heilige Gees in die mens. Hieruit is dit duidelik dat die mens in sy persoon eiewaarde besit en dat eerbied volg as reaksie teenoor die mens in wie so 'n waarde gerealiseer het.

Diep onder die indruk van die eerbied wat betoon moet word teenoor die ander persoon as 'God se besondere maaksel, sal in elke samelewingsverband die mens se gesindheid daardeur bepaal moet word' (Heyns 1986:104). Dit is juis binne hierdie samelewingsverbande dat sekere vooroordele teenoor ouer mense, die mindergegoedes of mense van mindere aansien dikwels gekoester word (vgl. Davies 2008; Malan \& Dreyer 2009; Nelson 2005; Krause 1996). In teenstelling daarmee dra ons uiterlike toestand en omstandighede by God geen gewig nie: 'Every man is, in the eye of God, what he is in his soul: if holy, loved; if wicked, despised and rejected' (Clarke 1831; vgl Hos 5:3; Jer 16:17; Ps 69:6).

Dat God geen onderskeid tref tussen mense nie, impliseer dat die afgetredene wat in finansiële nood verkeer en die afgetredene wat oorvloed geniet voor Hom gelykwaardig is (vgl. Ef 6:9; Jak 2:1, 5; Job 34:19; Kol 3:25; 1 Pet 1:17; Rom 2:11). Ons eiewaarde is dus nie aan ons nettowaarde gekoppel nie, maar aan ons identiteit in Christus. Wie ons is in Christus, beteken dat ons identiteit nie meer deur bloot kulturele paradigmas, rolle of identiteite bepaal word nie, maar deur ons nuwe status in Christus deur die inwoning van die Heilige Gees. De Jongh van Arkel (1986) maak die volgende opmerking:

The source of meaning lies beyond us: it derives from the encounter with the One from and through whom our lives acquire meaning. When the light of the gospel falls on me because it was intended for me, then I become meaningful, for then I realize that I am meaningful to God even in my old age. (p. 122)

\section{Erkenning Mededingende belange}

Die outeur verklaar dat sy geen finansiële of persoonlike verbintenis het met enige party wat haar nadelig of voordelig kon beïnvloed het in die skryf van hierdie artikel nie. 


\section{Literatuurverwysings}

Anderson, L., 2009, 'Pastoral care and the spiritual formation of older persons', Journal of religion, spirituality and aging 21, 104-118.

Atchley, R.C., 1982, 'Retirement: Leaving the World of Work', The Annals of the American Academy of Political and Social Science 464(1), 120-131, November.

BBC News, 1999, 'Money is the root of depression', viewed 21 April 2016, from http:// news.bbc.uk/2/hi/health/324900.stm

Bekker, J., 2009, 'Hier kom die oumens-ramp!' Die Burger, BY, 28 Februarie, bl. 14.

Braam, A.W., Delespaul, P., Beekman A.T.F., Deeg, D.J.H., Perés, K., Dewey, M., et al., 2004 'National context of health care, economy and religion, and the association between disability and depression in older Europeans', European Journal of Aging 1(1), 26-36.

Brunsdon, A.R. \& Lotter, G.A., 2008, 'Aftrede as integrasionele taak', Koers 73(2), 283-302.

Cherry, K., About.com Psychology, Psychology Glossary, viewed 19 April 2016, from http://www.psychology.about.com/od/sindex

Clarke, A., 1831, Commentary on the Bible, in e-Sword databasis, Bible software, 2015

Coetzer, W.J., 1993, 'Bedieningstrukture vir 'n bejaardebediening', PhD-proefskrif, Universiteit van Suid-Afrika.

Coetzer, W. \& Kotze, H., 2007, 'Metateoretiese perspektiewe op liggaamlike probleme', Acta Theologica 27(1), 1-21.

Coleman, P.G., Ivani-Chalian, C. \& Robinson, M., 1993, 'Self-esteem and its sources: Stability and change in later life', Aging and Society 13, 171-192.

Collins, G.R., 2005, Die A tot Z van Berading, Struik Christelike Boeke, Kaapstad.

Crocker, J. \& Major, B., 1989, 'Social Stigma and Self-esteem: The Self-protective Properties of Stigma', Psychological Review 96(4), 608-630.

Davies, J., 2008, 'A Practical Theology of Aging: Biblical Perspectives for Individuals and the Church', Christian Education Journal 3, 5(2), 275-293.

De Beer, E.J., 2011, “n Teologies-etiese beoordeling van aftrede', In die Skriflig 45(4), 803-823.

De Jongh van Arkel, J.T., 1986, 'Religion', in D.W. Steyn (ed.), Creative retirement, pp. 112,122 , Universiteit van Suid-Afrika, Pretoria.

De Klerk, B.J., 2005, "n Liturgie van Aftrede', In die Skriflig 39(3), 1-24.

Du Preez, L. \& Arde, A., 2011, 'Government will make you keep your savings until retirement', Personal Finance, 30 October 2011, viewed 21 April 2016, from http://www.iol.co.za/business/personal-finance/retirement/

Duvenage, A., 2009, Die Institusie van Calvyn, Calvyn Jubileum Boekefonds, Potchefstroom.

Ellison, C.G., 1991, 'Religious Involvement and Subjective Well-Being', Journal of Health and Social Behavior 32, 80-99, March.

Erickson, M.J., 2001, Introducing Christian Doctrine, 2nd edn., Baker Publishing Group Grand Rapids, MI.

Faurie, J., 2014, 'Increasing the retirement age', SANews, 23 July 2014, viewed 22 April 2016, from http://www.fanews.co.za./article/front-page-features/25/the-stage/ 1145/increasing-the-retirement-age/16411

Ferreira, L., 2016, 'Factsheet: Social grants in South Africa - separating myth from reality', viewed 27 April 2016, from https://africacheck.org/factsheets/separatingmyth-from-reality-a-guide-to-social-grants-in-south-africa/

Frankl, V., 1975, Waarom lewe ek, HAUM, Kaapstad.

Fry, P.S., 2000, 'Religious involvement, spirituality, and personal meaning for life: Existential predictors of spychological well-being in community-dwelling and institutional cared elders', Aging and Mental Health 4, 375-387.

Gerstein, K.K., 2013, Job search 50+: A Curriculum for adults over age 50 looking for employment, 1522573, California State University, Long Beach.

Goldenworkers, 2012, 'European year for active ageing and solidarity between generations', viewed 21 April 2016, from http://www.goldenworkers.org/index. php/workers-always-on-goldenworkers/111-a-contribute-from-adecco-partner

Gossop, M., 2008, 'Substance use among older adults: a neglected problem', Drugs in focus, European Monitoring Centre for Drugs and Drug Addiction, viewed 22 April
2016, from http://www.emcdda.europa.eu/attachements.cfm/att_50566 EN 2016, from http://www.

HealthinAging, 2012, 'Alcohol and drug abuse: Causes and Symptoms', viewed 22 Apri 2016, from http://www.healthinaging.org/aging-and-health-a-to-z/topic:drugand-substance-abuse/

Heyns, J.A., 1978, Dogmatiek, Nasionale Boekdrukkery, Kaapstad.

Heyns, J.A., 1986, Teologiese Etiek, NG Kerkboekhandel, Pretoria.

Hodge, D.R., Bonifas, R.P., \& Chou, R.J., 2010, 'Spirituality and Older Adults: Ethical Guidelines to Enhance Service Provision', Advances in Social Work 11(1), 1-16.

Joiner, T.E., Metalsky, G.I., Katz, J. \& Beach, S.R.H., 1999, 'Depression and Excessive Reassurance-Seeking', Psychological Inquiry 10(4), 269-278.

Keyes, C.L.M. \& Reitzes, D.C., 2007, 'The role of religious identity in the mental health of older working and retired adults', Aging \& Mental Health 11(4), 434-443, July.

Kim, J., Nesselroade, J.R. \& McCullough, M.E., 2009, 'Dynamic Factor Analysis of Worldviews/Religious Beliefs and Well-Being among Older Adults', Journal of Adult Development 16, 87-100.

Kleinschmidt, F.M.J., 2016, 'Pastorale begeleiding van afgetredenes met betrekking tot hul eiewaarde in finansiële nood', MA-verhandeling, Noordwes Universiteit, Potchefstroom.
Krause, N., 1996, 'Welfare participation and welfare in later life', The Gerontologist 23(5), 665-673.

Krause, N., 2004, 'Stressors arising in highly valued roles, meaning in life, and the physical health of older adults', Journal of Gerontology 59, 2287-2297.

Krause, N., 2006, 'Religious Doubt and Psychological Well-being: A Longitidunal Investigation', Review of Religious Research 47(3), 287-302.

Krause, N. \& Hayward, R.D., 2014, 'Religion, Finding Interests in Life, and Change in Self-Esteem During Late Life', Research on Aging 36(3), 364-381.

Krause, N. \& Trann, T.V., 1989, 'Stress and religious involvement among older Blacks', Journal of Gerontology 44, S4-S13.

Labuschagne, F.J. \& Eksteen, L.C., 2010, Verklarende Afrikaanse Woordeboek, Interpak Books, Pietermaritzburg.

Lamb, W.W.H. \& Thomson, H., 2001, "Wholeness, Dignity and the Ageing Self": A conversation between philosophy and theology', Journal of religious gerontology 12 (3\&4), 57-76.

Louw, D.J., 2012, 'A theological model for pastoral anthropology within the dynamics of interculturality: Cura animarum and the quest for wholeness in a colo spirituality', In die Skriflig/In Luce Verbi 46(2), Art. \# 57, 9 pages. http://dx.doi. org/10.4102/ids.v46i2.57

Malan, E. \& Dreyer, Y., 2009, 'Multidissiplinêre beskouing op veroudering vanuit ' $n$ pastorale perspektief', HTS Teologiese Studies/Theological Studies 65(1), Art. $\# 182,9$ pages. http://dx.doi.org/10.4102/hts.v65il.182

May, J., 2003, 'Chronic poverty and older people in South-Africa', MA dissertation, University of Natal, South Africa.

McLeod, S.A., 2008, 'Erik Erikson', viewed 22 April 2016, from http://www. simplypsychology.org/Erik-Erikson.html

Media Club South Africa, n.d., viewed 22 April 2016, from http://www. mediaclubsouthafrica.comlandstatic/82-fast-facts

Moneyweb, 2014, 'Medical inflation and price increases', viewed 27 April 2016, from http://www.moneyweb.co.za/archive/medical-inflation-and-price-increases/

Moreno-Weinert, I., 2011, 'The Influence of Religiosity on Psychological Well Being and Life Satisfaction in an Elderly Population', PhD thesis, Arizona State University.

Müller, P., 2013, 'The concept of retirement is changing', Sasol Pension Fund Trustee Report, March.

Müller, P. \& Stevens, C., 2001, Sukses na 50, Lapa Uitgewers, Pretoria.

Nelson, T.D., 2005, 'Ageism: Prejudice Against Our Feared Future Self', Journal of Social Issues 61(2), 207-221.

Nkabinde, S., 2016, 'Food price inflation marches on', viewed 21 April 2016, from http://www.moneyweb.co.za/news/economy/food-price-inflation-marches/

Orth, U., Robins, R.W. \& Meier, L.L., 2009, 'Disentangling the Effects of Low SelfEsteem and Stressful Events on Depression: Findings from Three Longitudinal Studies', Journal of Personality and Social Psychology 97(2), 307-321.

Osmer, R.R., 2008, Practical Theology: an introduction, Eerdmans, Grand Rapids, MI.

Patricelli, C., n.d., 'Stage of Grief Models: Kubler-Ross', viewed 20 April 2016, from http://www.amhc.org/58-grief-bereavement-issues/article/8444-stage-of-griefmodels-kubler-ross

Pickworth, E., 2014, 'Sanlam pushes to extend retirement age in South Africa', Business Day Live, 14 May viewed 21 April 2016, from http://www.bdlive.co.za/ business/financial/2014/05/14/sanlam-pushes-to-extend-retirement-age-in-sa

Pinquart, M., 2002, 'Creating and maintaining purpose in life in old age: A metaanalysis', Aging International 27, 90-114.

Ramashala, M.F., 2001, 'Living arrangements, poverty and the health of older persons in Africa', viewed 20 April 2016, from http://www.un.org/esa/population/ publications/bulletin42_43/ramashala.pdf

Ramezani, A., 2011, 'Aging with dignity', PhD thesis, Carleton University, Ottawa, Canada.

Rank, M.R., 1994, 'A View From the Inside Out: Recipients Perception of Welfare', Journal of Sociology and Social Welfare 27, 27-47.

Reitzes, D.C. \& Mutran, E.J., 2002, 'Self-concept as the organization of roles: Importance, centrality, and balance', Sociological Quaterly 43, 647-667.

Reitzes, D.C., Mutran, E.J. \& Fernandez, M.E., 1996, 'Does Retirement Hurt WellBeing? Factors Influencing Self-Esteem and Depression Among Retirees and Workers', The Gerontologist 36(5), 649-656.

Sarason, I.G., Pierce, G.R. \& Sarason, B.R., 1994, 'General and Specific Perceptions of Social Support' in W.R. Avison \& I.A. Gotlib (eds.), Stress and Mental Health, Contemporary Issues and Prospects for the Future, pp. 151-178, Plenum Press, New York.

Shreve-Neiger, A.K., 2002, 'The Relation Between Spirituality, Religiosity and Reasons for Living in Older Adults', MA dissertation, West Virginia University, West Virginia.

Smit, F., 2011, 'Demografie - die toekoms wat reeds gebeur het: wêreldtendense met spesiale verwysing na Suid-Afrika', Tydskrif vir Geesteswetenskappe 51(1), 86-100.

Snodgrass, J. \& Sorajiakool, S., 2011, 'Spirituality in Older Adulthood: Existential Meaning, Productivity, and Life Events', Pastoral Psychology 60, 85-94.

Statistics SA, n.d., The South Africa I know, the home I understand, viewed 20 April 2016, from http://www.statssa.gov.za/

Taborda, J., 2016, 'Trading economics, South Africa Inflation Rate 1968-2016', viewed 20 April 2016, from http://www.tradingeconomics.com/south-africa/inflation-cp

Twenge, J.M. \& Campbell, W.K., 2002, 'Self-esteem and socioeconomic status: A metaanalytic review', Personality and Social Psychology Review 6, 59-71. 
Vaktaalkomitee vir Maatskaplike werk, 1995, Nuwe woordeboek vir maatskaplike werk: Hersiene en uitgebreide uitgawe, CTP Book Printers, Kaapstad.

Vorster, J.M., 2007, Christian attitude in the South African liberal democracy, V\&R Printing Works, Pretoria.
Watson, L., Van Zyl, A. \& Saayman, C., 2013, 'Hou kop met aftreegeld', Die Burger, Sake24, 25 Mei, bl. 15, 18.

Wheaton, B., 1994, 'Sampling the Stress Universe', in W.R. Avison \& I.A. Gotlib, (eds.), Stress and Mental Health, Contemporary Issues and Prospects for the Future, pp. 77-113, Plenum Press, New York. 